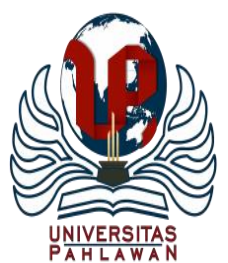

Edukatif : Jurnal Ilmu Pendidikan Volume 3 Nomor 6 Tahun 2021 Halm 3579 - 3592

EDUKATIF: JURNAL ILMU PENDIDIKAN

Research \& Learning in Education

https://edukatif.org/index.php/edukatif/index

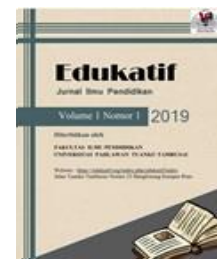

\title{
Hubungan antara Locus Of Control dan Perfeksionisme dengan Prokrastinasi Akademik pada Mahasiswa Akuntansi
}

\author{
Isni Mardiani $^{1 凶}$, Sri Zulaihati², Ati Sumiati ${ }^{3}$ \\ Universitas Negeri Jakarta, Indonesia ${ }^{1,2,3}$ \\ E-mail : $\underline{\text { isnimardiani28@ gmail.com }}{ }^{1}, \underline{\text { srizulaihati@unj.ac.id }}^{2}, \underline{\text { ati-sumiati@ unj.ac.id }}^{3}$
}

\begin{abstract}
Abstrak
Locus of control dan perfeksionisme merupakan faktor yang mengakibatkan terjadinya prokrastinasi akademik. Penelitian ini bertujuan untuk mengetahui apakah ada hubungan locus of control dan perfeksionisme dengan prokrastinasi akademik pada mahasiswa. Metode penelitian menggunakan pendekatan korelasional dan jenis data kuantitatif, populasi penelitian sebanyak 266 mahasiswa dengan jumlah sampel 152 mahasiswa Akuntansi dan Pendidikan Akuntansi Universitas Negeri Jakarta. Teknik pengumpulan data meggunakan kuesioner lalu data dianalisis menggunakan statistik deskriptif, uji normalitas, uji linieritas, persamaan regresi berganda, uji f, uji t dan analisis koefisien determinasi dengan bantuan aplikasi SPSS versi 26. Hasil penelitian ini yaitu 1) Ada hubungan negatif antara locus of control dengan prokrastinasi akademik, 2) Tidak ada hubungan positif antara perfeksionisme dengan prokrastinasi akademik dan 3)Ada hubungan antara locus of control dan perfeksionisme secara bersama-sama dengan prokrastinasi akademik. Kesimpulannya semakin rendah tingkat locus of control dan semakin tinggi tingkat perfeksionisme yang dimiliki mahasiswa maka semakin tinggi tingkat prokrastinasi akademik pada mahasiswa, begitupun sebaliknya.
\end{abstract}

Kata Kunci: locus of control, perfeksionisme, prokrastinasi akademik.

\begin{abstract}
Locus of control and perfectionism are factors that lead to academic procrastination. This study aims to determine whether there is a relationship between locus of control and perfectionism with academic procrastination in students. The research method uses a correlational approach and quantitative data types, the research population is 266 students with a total sample of 152 students of Accounting and Accounting Education, State University of Jakarta. Data collection techniques using questionnaires and data analysis using descriptive statistical tests, normality tests, linearity tests, multiple equations, $f, t$ tests and analysis of the coefficient of determination with the help of SPSS version 26 application. The results of this study are 1) There is a negative relationship between locus of control and academic procrastination, 2) There is no positive relationship between perfectionism and academic procrastination and 3) There is a relationship between locus of control and perfectionism together with academic procrastination. In conclusion, the lower the level of locus of control and the higher the level of perfectionism possessed by students, the higher the level of academic procrastination in students, and vice versa.
\end{abstract}

Keywords: locus of control, perfectionism, academic procrastination.

Copyright (c) 2021 Isni Mardiani, Sri Zulaihati, Ati Sumiati

$\triangle$ Corresponding author

Email : isnimardiani28@gmail.com

DOI : https://doi.org/10.31004/edukatif.v3i6.805

ISSN 2656-8063 (Media Cetak)

ISSN 2656-8071 (Media Online)

Edukatif : Jurnal Ilmu Pendidikan Vol 3 No 6 Tahun 2021 p-ISSN 2656-8063 e-ISSN 2656-8071 
3580 Hubungan antara Locus Of Control dan Perfeksionisme dengan Prokrastinasi Akademik pada Mahasiswa Akuntansi - Isni Mardiani, Sri Zulaihati, Ati Sumiati

DOI: https://doi.org/10.31004/edukatif.v3i6.805

\section{PENDAHULUAN}

Pendidikan sebagai upaya untuk memajukan budi pekerti, pikiran, dan jasmani melalui proses pembelajaran supaya siswa dapat secara efektif membangun potensinya, dengan kekuatan spiritual, control diri,karakter, pengetahuan, akhlak mulia, dan kemampuan yang dibutuhkan untuk diri mereka, masyarakat, bangsa, dan negara. Pendidikan dapat diselesaikan secara formal maupun nonformal. Pendidikan formal seperti perguruan tinggi berperan dalam menghasilkan manusia yang bermartabat, mandiri, kuat, dan kreatif. Oleh karena itu, tidak mudah untuk menjalani proses pembelajaran di perguruan tinggi. Sebagaimana mahasiswa tentu akan dihadapkan pada rutinitas kegiatan belajar, mengerjakan tugas dari dosen, tugas akhir atau skripsi dan lain sebagainya. Banyak kegiatan dan tugas yang harus diselesaikan mahasiswa maka diperlukan pengaturan waktu yang tepat supaya semua kegiatan dapat berjalan dengan lancer dan tugas dapat diselesaikan tepat pada waktunya.

Faktanya tidak semua mahasiswa memiliki pengaturan waktu yang baik, hal inilah yang menjadi permasalahan bagi sebagian mahasiswa. Beberapa mahasiswa melakukan penundaan pengerjaan tugas kuliah, menunda untuk belajar ketika akan menghadapi ujian, menunda menyelesaikan skripsi dan bahkan memilih untuk melakukan kegiatan yang lebih menarik dari pada mengerjakan tugasnya. Jenjang pendidikan di perguruan tinggi memiliki periode waktu dimana bagi mahasiswa tingkat sarjana harus menyelesaikan tugas akhir yang disebut skripsi. Tuntutan skripsi yang harus diselesaikan tepat waktu cenderung membuat mahasiswa tertekan dan bahkan mahasiswa menunda mengerjakan skripsinya. Basri (2018) mengungkapkan bahwa masa belajar 5 tahun atau lebih menunjukkan indikasi penundaan akademik. Indikasi yang disebutkan tersebut dinamakan prokrastinasi akademik. Pujiyanti (2017) memperkirakan persentase mahasiswa yang telah menjadi prokrastinator sebesar $90 \%$, persentase penunda jangka panjang yang biasanya berakhir mundur dari perguruan tinggi sebesar $25 \%$. Terlihat dari perkiraan tersebut bahwa persentase prokrastinasi mahasiswa tergolong cukup tinggi.

Penelitian lain juga menunjukkan bahwa tingkat prokrastinasi mahasiwa tergolong tinggi seperti penelitian Batubara \& Asriatuzzekya (2017) kepada mahasiswa menunjukkan tingkat prokrastinasi mahasiswa sebesar 71,84\%. Dalam penelitian ini menunjukan locus of control berkaitan dengan kepercayaan mahasiswa berdasarkan locus of control yang dimilikinya sehingga locus of control sebagai salah satu faktor yang berkontribusi dalam penundaan tugas mahasiswa. Kepercayaan individu dengan penyebab sukses dan gagal merupakan hal yang sangat penting, artinya memahami perilaku yang berkaitan dengan pencapaian kesuksesan. Hal ini berkaitan dengan konsep internal dan external locus of control, mahasiswa dengan locus of control eksternal akan kurang usaha, kurang gigih, tidak aktif, dan pasrah pada nasib atau takdir. Hal tersebut mengakibatkan penurunan aktivitas dan kualitas kegiatan pembelajaran mahasiswa. Mahasiswa dengan locus of control internal akan berusaha untuk gigih dan rajin, sebab merasa dan yakin bahwa yang diperoleh merupakan usaha dan kerja keras sendiri yang diwujudkan dalam pekerjaan, kemampuan, dan keterampilannya. Keyakinan yang menyertai perilaku dan tindakan ini akan memberikan semangat untuk menyelesaikan tugas tepat pda waktunya dan menghindari prokrastinasi akademik.

Berdasarkan penelitian (Philip, 2012) dan (Boysan \& Kiral, 2016) menemukan antara locus of control dengan prokrastinasi tidak ada hubungan. Namun pada kenyataannya mahasiswa meyakini sesuatu yang diperoleh disebabkan oleh faktor internal dalam dirinya, sehingga mahasiswa cenderung melakukan locus of control internal. Walaupun mahasiswa percaya sesuatu yang diterima dikarenakan oleh faktor eksternal luar dirinya, mahasiswa cenderung melakukan eksternal locus of control. Maka locus of control inilah perilaku yang penting dibahas dan berkaitan dengan prokrastinasi akademik. Misalnya fenomena pada mahasiswa yang sedang mengerjakan skripsi, mereka percaya bahwa banyak orang masih melakukan kegiatan lain yag lebih menarik. Aktivitas itu seperti bermain game di laptop, online dan mengobrol di media sosial, mendengarkan musik walaupun sebenarnya tujuan awal mahasiswa memanfaatkan media wifi yang tersedia untuk pengerjaan 
3581 Hubungan antara Locus Of Control dan Perfeksionisme dengan Prokrastinasi Akademik pada Mahasiswa Akuntansi - Isni Mardiani, Sri Zulaihati, Ati Sumiati

DOI: https://doi.org/10.31004/edukatif.v3i6.805

tugas akan tetapi pada akhirnya mereka meninggalkan tugas dengan mencari aktivitas lain yang lebih menyenangkan. Faktor internal locus of control semacam ini terkait dengan prokrastinasi akademik mahasiswa, mahasiswa meyakini bahwa prokrastinasi yang dialami disebabkan memilih meninggalkan mengerjakan skripsi karena tidak tidak bisa melakukan penundaan kesenangan.

Selain faktor locus of control, masih ada faktor lain yang dapat berkaitan dengan prokrastinasi. Lasari, Marjohan, \& Karneli (2019) menyebutkan bahwa faktor yang menyebabkan prokrastinasi akademik selain locus of control yaitu perfeksionisme. Individu perfeksionis memaksakan standar tinggi yang tidak rasional pada diri sendiri dan menunjukkan penundaan karena mereka tidak percaya bahwa mereka dapat memenuhi standar tersebut. Perfeksionisme maladaptif biasanya tidak realistis dalam menetapkan tujuan atau mengevaluasi kinerja sebenarnya, karena itu perfeksionisme maladaptif berkaitan dengan prokrastinasi (Kurtovic, Vrdoljak, \& Idzanovic, 2019).

(Srantih, 2014) dan (Rice, Richardson, \& Clark, 2012) mengemukakan bahwa antara perfeksionisme dengan prokrastinasi akademik tidak terdapat pengaruh yang signifikan. Namun pada kenyataannya perfeksionisme adalah bentuk realisasi diri, melibatkan ambisi untuk mencapai hasil terbaik, menuntut segala sesuatu sempurna yang irasional, dan sulit menerima sesuatu jika tidak selaras dengan harapan seseorang dan tidak sempurna. Karena ketakutan akan kegagalan dan merasa kurang percaya diri, perfeksionisme terkait dengan obsesi akan kesempurnaan. Oleh karena itu, perfeksionisme yang disebabkan oleh rasa takut gagal dan keyakinan yang tidak masuk akal menyebabkan penundaan.

Penelitian Prokrastinasi akademik terdapat peneliti lain yang meneliti dan setiap peneliti menggunakan variabel yang berbeda. Ditemukan beberapa penelitian yang berjudul hubungan locus of control dengan prokrastinasi akademik, hubungan perfeksionisme dengan prokrastinasi akademik, dan lain-lain. Namun hanya sedikit yang melaksanakan penelitian hubungan antara locus of control dan perfeksionisme dengan prokrastinasi akademik. Penelitian (Xie, Yang, \& Chen, 2018) menunjukkan bahwa usaha perfeksionis secara negatif terkait dengan penundaan, sedangkan kekhawatiran perfeksionis secara positif terkait dengan penundaan. Tiga dimensi perfeksionisme (kekhawatiran atas kesalahan, kritik orang tua, dan keraguan tentang tindakan) ditemukan berkorelasi positif dan signifikan dengan penundaan akademik dan dimensi organisasi berkorelasi negatif dan signifikan dengannya (Jadidi, Mohammadkhani, \& Tajrishi, 2011). Penelitian (Sutrisno, Rini, \& Pratitis, 2018) menemukan locus of control internal dan Prokrastinasi mempunyai hubungan negatif dan sangat signifikan sedangkan locus of control external dan variabel Prokrastinasi mempunyai hubungan positif dan sangat signifikan. Namun dalam penelitiannya mengenai prokrastinasi dan locus of control menginginkan variabel lain ditambahkan yang dapat memberikan hasil komprehensif tentang prokrastinasi. Variabel tersebut seperti manajemen waktu, perfeksionis, kecemasan, motivasi berprestasi, dll untuk melanjutkan penelitian atas topik yang sama. Berdasarkan hal tersebut peneliti menambahkan variabel perfeksionisme untuk diteliti hubungannya dengan prokrastinasi akademik. Kemudian penelitian yang sama dilakukan (S. A. Purnomo \& Izzati, 2013) hasil penelitian menunjukkan bahwa terdapat hubungan negatif yang signifikan antara Internal locus of control dengan prokrastinasi akademik. Dalam penelitian ini selain locus of control internal, faktor lain terkait prokrastinasi akademik yang dapat dikaji lebih lanjut adalah faktor kontrol diri, faktor dukungan sosial, faktor kepribadian, faktor sikap dan keyakinan serta faktor motivasi berprestasi.

Penelitian sebelumnya yang sama dengan penelitian ini yaitu penelitian (Lasari et al., 2019). Namun dalam penelitian sebelumnya dengan penelitian ini terletak perbedaan pada objek penelitian, subjek penelitian dan indikator variabel prokrastinasi akademik. Objek dan subjek dalam penelitian sebelumnya ditujukan kepada siswa di sekolah, sedangkan penelitian ini ditujukan kepada mahasiswa di universitas. Selain itu pada penelitian sebelumnya digunakan delapan indikator untuk variabel prokrastinasi akademik sedangkan pada penelitian ini digunakan empat indikator. Indikator yang digunakan dalam penelitian sebelumnya antara lain tidak dapat mengefektifkan waktu belajar, penolakan untuk menghindari waktu belajar, memulai dan 
menyelesaikan PR, menunda untuk memulai menyelesaikan tugas, menunda menyelesaikan tugas, menunda memulai mengerjakan tugas, tidak konsisten dalam mengerjakan PR, bermain, dan kesulitan dalam memnuhi jadwal belajar, sedangkan indikator penelitian ini diantaranya melakukan aktivitas yang lebih menyenangkan, kesenjangan waktu antara rencana dan kinerja actual, keterlambatan dalam mengerjakan tugas serta penundaan untuk memulai dan menyelesaikan tugas. Selain itu, penelitian dilakukan oleh (Pearlman-Avnion \& Harduf, 2019), Perbedaan penilitian sebelumnya dengan penelitian saat ini terdapat pada indikator variabel locus of control. Pada penelitian sebelumnya Indikator variabel locus of control diantaranya internality dan eternality powerfull other, dan chance, sedangkan dalam penelitian ini diukur melalui aspek internal dan aspek eksternal.

Adapun tujuan dari penelitian ini adalah untuk melihat: (1) Hubungan antara locus of control dengan prokrastinasi akademik pada mahasiswa. (2) Hubungan antara perfeksionisme dengan prokrastinasi akademik pada mahasiswa. (3) Hubungan antara locus of control dan perfeksionisme dengan prokrastinasi akademik pada mahasiswa. Pentingnya penelitian ini yaitu dapat meningkatkan keyakinan atas kemampuan mengontrol diri dan mengurangi perfeksionisme yang mengarah pada hal negatif dalam kaitannya dengan penundaan akademik pada mahasiswa.

\section{METODE PENELITIAN}

Populasi pada penelitian ini adalah seluruh mahasiswa S1 Akuntansi dan Pendidikan Akuntansi Fakultas Ekonomi Universitas Negeri Jakarta sebanyak 266 mahasiswa terdiri dari 16 mahasiswa pendidikan akuntansi angkatan 2016, 47 mahasiswa akuntansi angkatan 2016, 87 mahasiswa pendidikan akuntansi angkatan 2017, dan 116 mahasiswa akuntansi angkatan 2017. Sedangkan sampel penelitian menggunakan teknik sampel propotional random sampling. Populasi memiliki kesempatan pada setiap kelas untuk dijadikan sampel. Tingkat kesalahan 5\% dengan menggunakan Tabel Isac dan Michael untuk menentukan sampel. Berdasarkan perhitungan jumlah sampel pada mahasiswa S1 Akuntansi dan Pendidikan Akuntansi Fakultas Ekonomi Universitas Negeri Jakarta sebanyak 152 mahasiswa terdiri dari 9 mahasiswa Pendidikan Akuntansi angkatan 2016, 27 mahasiswa Akuntansi angkatan 2016, 50 mahasiswa Pendidikan Akuntansi angkatan 2017, dan 66 mahasiswa Akuntansi angkatan 2017.

Variabel bebas yaitu locus of control $\left(\mathrm{X}_{1}\right)$, perfeksionisme $\left(\mathrm{X}_{2}\right)$, sedangkan variabel terikat yaitu Prokrastinasi Akademik (Y). Penelitian ini menggunakan pendekatan korelasional dan jenis data kuantitatif. Pendekatan korelasional digunakan untuk melihat hubungan antara dua atau lebih variabel. Rancangan penelitian adalah kuesioner locus of control, kuesioner perfeksionisme, kuesioner prokrastinasi akademik sebagai berikut.

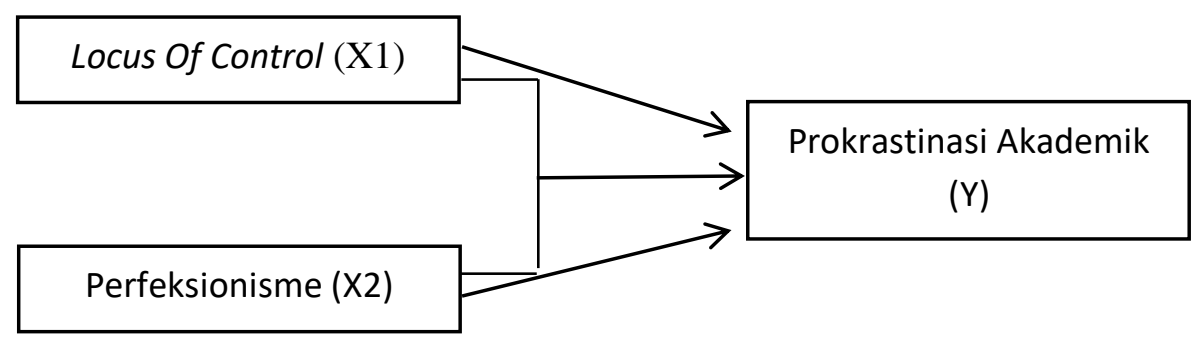

Gambar 1: Konstelasi Hubungan Antar Variabel

Keterangan :

$\begin{array}{ll}\rightarrow & : \text { Arah Hubungan } \\ \mathrm{Y} & : \text { Variabel Terikat } \\ \mathrm{X}_{1} & \text { : Variabel Bebas } \\ \mathrm{X}_{2} & \text { : Variabel Bebas }\end{array}$


3583 Hubungan antara Locus Of Control dan Perfeksionisme dengan Prokrastinasi Akademik pada Mahasiswa Akuntansi - Isni Mardiani, Sri Zulaihati, Ati Sumiati

DOI: https://doi.org/10.31004/edukatif.v3i6.805

Langkah-langkah pada penelitian ini yaitu: (1) Merancang instrumen penelitian yang terdiri dari kuesioner locus of control, kuesioner perfeksionisme dan kuesioner prokrastinasi akademik; (2) Melakukan uji coba instrumen penelitian untuk memperoleh instrumen yang valid dan realibilitas; (3) Menyebarkan kuesioner penelitian secara online melalui google form untuk mengetahui locus of control, perfeksionisme dan prokrastinasi akademik; (4) Melakukan pengolahan data; (5) Melakukan analisis data; (6) Menjabarkan pembahasan; dan (7) Membuat kesimpulan penelitian.

Dalam memperoleh data penelitian maka digunakan langkah-langkah sebagai berikut:

\section{Kuesioner Locus Of Control}

Pengambilan data yang digunakan adalah metode survei dengan kuesioner dan menggunakan skala likert. Bentuk skala likert pada hasil penelitian ini diperoleh dari skor yang didapatkan dari setiap jawaban butir pertanyaan. Locus of control menggunakan indikator diantaranya locus of control internal serta locus of control eksternal. Locus of control internal terdiri dari minat, usaha dan kemampuan. Locus of control eksternal terdiri dari nasib, sosial ekonomi, pengaruh orang lain (Fadila, 2016).

Item pernyataan pada kuesioner terdiri dari pernyataan positif dan negatif. Untuk pernyataan positif, jika mahasiswa memilih option SS (Sangat Setuju) diberi skor 5, option S (Setuju) diberi skor 4, option RR (Ragu-Ragu) diberi skor 3, option TS (Tidak Setuju) diberi skor 2, dan option STS (Sangat Tidak Setju) diberi skor 1. Untuk pernyataan negatif, jika mahasiswa memilih option SS (Sangat Setuju) diberi skor 1, option S (Setuju) diberi skor 2, option RR (Ragu-Ragu) diberi skor 3, option TS (Tidak Setuju) diberi skor 4, dan option STS (Sangat Tidak Setju) diberi skor 5. Skor tertinggi dari hasil kuesioner untuk 27 item pernyataan adalah 135, dan skor terendah adalah 27.

\section{Kuesioner Perfeksionisme}

Pengambilan data yang digunakan adalah metode survei dengan kuesioner dan menggunakan skala likert. bentuk skala likert pada hasil penelitian ini diperoleh dari skor yang didapatkan dari setiap jawaban butir pertanyaan. Perfeksionisme diukur dengan menggunakan indikator, diantaranya memperhatikan kesalahan, penetapan standar tinggi, tekanan dari orang tua, keraguan dengan tindakan yang akan dilakukan, mengorganisir dalam melakukan sesuatu (Arshuha \& Amalia, 2019).

Item pernyataan pada kuesioner terdiri dari pernyataan positif. Untuk pernyataan positif, jika mahasiswa memilih option SS (Sangat Setuju) diberi skor 5, option S (Setuju) diberi skor 4, option RR (Ragu-Ragu) diberi skor 3, option TS (Tidak Setuju) diberi skor 2, dan option STS (Sangat Tidak Setuju) diberi skor 1. Skor tertinggi dari hasil kuesioner untuk 22 item pernyataan adalah 110, dan skor terendah adalah 22.

\section{Kuesioner Perokrastinasi Akademik}

Pengambilan data yang digunakan adalah metode survei dengan kuesioner dan menggunakan skala likert. Bentuk skala likert pada hasil penelitian ini diperoleh dari skor yang didapatkan dari setiap jawaban butir pertanyaan. Prokrastinasi akademik diukur melalui kesenjangan waktu antara rencana dan kinerja aktual, melakukan aktivitas yang lebih menyenangkan, keterlambatan dalam mengerjakan tugas, dan penundaan untuk memulai dan menyelesaikan tugas (Ghufron \& Suminta, 2017).

Item pernyataan pada kuesioner terdiri dari pernyataan positif. Untuk pernyataan positif, jika mahasiswa memilih option SS (Sangat Setuju) diberi skor 5, option S (Setuju) diberi skor 4, option RR (Ragu-Ragu) diberi skor 3, option TS (Tidak Setuju) diberi skor 2, dan option STS (Sangat Tidak Setju) diberi skor 1. Skor tertinggi dari hasil kuesioner untuk 18 item pernyataan adalah 90, dan skor terendah adalah 18.

Teknik analisis data yang digunakan pada penelitian ini adalah statistic deskriptif. Gambaran hasil pengolahan data yang dilakukan penulis dinamakan deskripsi data. Menurut (R. A. Purnomo, 2017) pengujian data berdistribusi normal maupun tidak sebelumnya perlu dilakukan uji normalitas data. Statistik yang dapat digunakan dalam menguji normalitas yaitu Kolmonogrov-Smirnov untuk menguji apakah berdistribusi normal atau mendekaati normal atau bisa dianggap normal (Ismail, 2018). Data berdistribusi normal jika signifikasi > 0,05 . Uji persyaratan yang bertujuan mengetahui hubungan linier maupun tidak antara variabel $\mathrm{X}$ dan variabel 
3584 Hubungan antara Locus Of Control dan Perfeksionisme dengan Prokrastinasi Akademik pada Mahasiswa Akuntansi - Isni Mardiani, Sri Zulaihati, Ati Sumiati

DOI: https://doi.org/10.31004/edukatif.v3i6.805

Y dinamakan uji linieritas. Menurut (Winarsunu, 2017) suatu proses yang digunakan untuk mencari tahu linieritas sebaran data penelitian disebut Uji linieritas. Model regresi yang baik mempunyai hubungan linier. Hubungan linear apabila nilai signifikansi pada Deviation From linierity $>0,05$.

(Priyatno, 2010) mengemukakan bahwa analisis yang menggunakkan persamaan linier untuk mengetahui hubungan antara variabel independen dengan variabel dependen dinamakan analisis regresi linier berganda. Memprediksi nilai dari variabel terikat jika nilai variabel bebas mengalami kenaikan atau penurunan sebagai tujuan analisis regresi berganda. Persamaan regresi linier berganda sebagai berikut:

$$
\hat{\mathrm{Y}}=\mathrm{a}+\mathrm{b} 1 \mathrm{X} 1+\mathrm{b} 2 \mathrm{X} 2
$$

Keterangan :

$\hat{Y} \quad$ : Variabel terikat (Prokrastinasi Akademik)

a $\quad$ : Konstanta (Nilai Y $\hat{Y}$, apabila X1, X2, ...., Xn $=0$ )

b1 : Koefisien regresi variabel bebas pertama

X1 : Variabel bebas pertama (Locus Of Control)

b2 : Koefisien regresi variabel bebas kedua

X2 : Variabel bebas kedua (Perfeksionisme )

Uji hipotesis dilakukan dengan uji f dan uji t. Uji yang digunakan untuk mengetahui pengaruh signifikan variabel independen terhadap variabel dependen secara bersamaan yaitu menggunakan Uji F. Rumus uji $F$ hitung sebagai berikut:

$$
\begin{gathered}
\text { Fhitung }=\frac{\frac{R^{2}}{k}}{\frac{\left(1-R^{2}\right)}{(n-k-1)}} \\
\text { atau } \\
\text { Fhitung }=x=\frac{R^{2}}{\frac{\left(1-R^{2}\right)}{(n-k-1)}}
\end{gathered}
$$

Keterangan :

$\mathrm{R} 2=$ Koefisien determinasi

$\mathrm{N}=$ jumlah data

$\mathrm{K}=$ Jumlah variabel independen

Variabel X1 (locus of control) dan X2 (perfesionisme) secara serentak berpengaruh terhadap Y jika $H_{\mathrm{a}}$ : $\mathrm{b}_{1} \neq \mathrm{b}_{2} \neq 0 . H_{0}$ diterima jika $\mathrm{F}$ hitung $\leq \mathrm{F}$ kritis. (Priyatno, 2010) mengungkapkan bahwa untuk menguji pengaruh variabel independen secara parsial terhadap variabel dependen menggunakan uji koefisien regresi secara pasial (Uji t). $\mathrm{H}_{0}$ diterima jika $\mathrm{t}_{\text {hitung }}>\mathrm{t}_{\text {tabel }}$ atau $-\mathrm{t}_{\text {hitung }}<-\mathrm{t}_{\text {tabel. }}$

(Priyatno, 2010) mengemukakan bahwa untuk mengetahui presentase kontribusi hubungan variabel independen secara bersama-sama terhadap variabel dependen menggunakan analisis $\mathrm{R} 2(R$ square $)$ atau koefisien determinasi. Selanjutnya rumus koefisien determinan digunakan untuk menyatakan besar kecilnya sumbangan variabel $\mathrm{X}$ terhadap $\mathrm{Y}$ dapat ditentukan dengan sebagai berikut:

$$
\mathrm{KP}=\mathrm{R}^{2} \times 100 \%
$$

Keterangan:

$\mathrm{KP}=$ Nilai Koefisien Penentu atau Koefisien Determiasi $\left(\mathrm{R}^{2}\right)$

$\mathrm{R} \quad=$ Nilai Koefisien Korelasi.

\section{HASIL DAN PEMBAHASAN PENELITIAN}

Hasil analisis deskriptif locus of control mahasiswa Pendidikan Akuntansi dan Akuntansi Fakultas Ekonomi Universitas Negeri Jakarta (X1) dapat dilihat pada Gambar tabel 1 berikut : 
3585 Hubungan antara Locus Of Control dan Perfeksionisme dengan Prokrastinasi Akademik pada Mahasiswa Akuntansi - Isni Mardiani, Sri Zulaihati, Ati Sumiati

DOI: https://doi.org/10.31004/edukatif.v3i6.805

Tabel 1. Deskripsi Locus Of Control Mahasiswa Pendidikan Akuntansi dan Akuntansi Fakultas Ekonomi Universitas Negeri Jakarta

\begin{tabular}{ccccc}
\hline Kelas & Batas Bawah & Batas Atas & Fr. Absolute & Fr. Relative(\%) \\
\hline $59-66$ & 58,5 & 66,5 & 3 & $1,97 \%$ \\
\hline $67-74$ & 66,5 & 74,5 & 6 & $3,95 \%$ \\
\hline $75-82$ & 74,5 & 82,5 & 20 & $13,16 \%$ \\
\hline $83-90$ & 82,5 & 90,5 & 43 & $28,29 \%$ \\
\hline $91-98$ & 90,5 & 98,5 & 41 & $26,97 \%$ \\
\hline $99-106$ & 98,5 & 106,5 & 24 & $15,79 \%$ \\
\hline $107-114$ & 106,5 & 114,5 & 13 & $8,55 \%$ \\
\hline $115-122$ & 114,5 & 122,5 & 2 & $1,32 \%$ \\
\hline TOTAL & & & 152 & $100 \%$ \\
\hline
\end{tabular}

Hasil analisis deskriptif perfeksionisme mahasiswa Pendidikan Akuntansi dan Akuntansi Fakultas Ekonomi Universitas Negeri Jakarta (X2) dapat dilihat pada Gambar tabel 2 berikut :

Tabel 2. Deskripsi Perfeksionisme Mahasiswa Pendidikan Akuntansi dan Akuntansi Fakultas Ekonomi Universitas Negeri Jakarta

\begin{tabular}{ccccc}
\hline Kelas & Batas Bawah & Batas Atas & Fr. Absolute & Fr. Relative (\%) \\
\hline $45-51$ & 44,5 & 50,5 & 3 & $1,97 \%$ \\
\hline $52-58$ & 50,5 & 57,5 & 3 & $1,97 \%$ \\
\hline $59-65$ & 57,5 & 64,5 & 8 & $5,26 \%$ \\
\hline $66-72$ & 64,5 & 71,5 & 45 & $29,61 \%$ \\
\hline $73-79$ & 71,5 & 78,5 & 50 & $32,89 \%$ \\
\hline $80-86$ & 78,5 & 85,5 & 25 & $16,45 \%$ \\
\hline $87-93$ & 85,5 & 92,5 & 12 & $7,89 \%$ \\
\hline $101-107$ & 100,5 & 107,5 & 2 & $1,32 \%$ \\
\hline TOTAL & & & 152 & $100 \%$ \\
\hline
\end{tabular}

Hasil analisis deskriptif Prokrastinasi Akademik Mahasiswa Pendidikan Akuntansi dan Akuntansi Fakultas Ekonomi Universitas Negeri Jakarta (Y) dapat dilihat pada Gambar tabel 3 berikut :

Tabel 3. Deskripsi Prokrastinasi Akademik Mahasiswa Pendidikan Akuntansi dan Akuntansi Fakultas Ekonomi Universitas Negeri Jakarta

\begin{tabular}{|c|c|c|c|c|}
\hline Kelas & Batas Bawah & Batas Atas & Fr.Absolute & Fr. Relative $(\%)$ \\
\hline $24-30$ & 23,5 & 30,5 & 6 & $3,95 \%$ \\
\hline $31-37$ & 30,5 & 37,5 & 10 & $6,58 \%$ \\
\hline $38-44$ & 37,5 & 44,5 & 20 & $13,16 \%$ \\
\hline $45-51$ & 44,5 & 51,5 & 33 & $21,71 \%$ \\
\hline $52-59$ & 51,5 & 59,5 & 37 & $24,34 \%$ \\
\hline $60-66$ & 59,5 & 66,5 & 25 & $16,45 \%$ \\
\hline $67-73$ & 66,5 & 73,5 & 14 & $9,21 \%$ \\
\hline $74-80$ & 73,5 & 80,5 & 7 & $4,61 \%$ \\
\hline TOTAL & & & 152 & $100 \%$ \\
\hline
\end{tabular}

Pada uji persyaratan analisis yang pertama kali dilakukan yaitu uji normalitas. Menggunakan bantuan SPSS versi 26.0, berikut ini output berupa plot uji normalitas: 
3586 Hubungan antara Locus Of Control dan Perfeksionisme dengan Prokrastinasi Akademik pada Mahasiswa Akuntansi - Isni Mardiani, Sri Zulaihati, Ati Sumiati

DOI: https://doi.org/10.31004/edukatif.v3i6.805

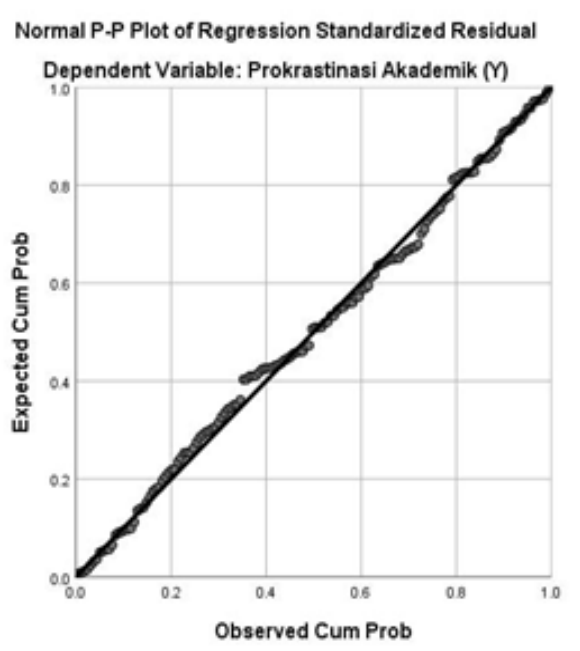

Gambar 2: Hasil Uji Normalitas

Berdasarkan gambar di atas diketahui bahwa titik-titik data terdapat di sekitar garis diagonal serta mengikuti arah garis diagonal, sehingga disimpulkan bahwa data pada variabel Locus Of Control (X1), Perfeksionisme (X2), dan Prokrastinasi Akademik (Y) berdstribusi normal dan dapat diuji analisis lebih lanjut karena model regresi telah memenuhi persyaratan asumsi normalitas. Menggunakan SPSS 26.0, berikut hasil perhitungan uji linearitas:

Tabel 4. Hasil Perhitungan Uji Linieritas

\begin{tabular}{|c|c|c|c|c|c|c|c|}
\hline \multicolumn{8}{|c|}{ ANOVA Table } \\
\hline & & & $\begin{array}{l}\text { Sum of } \\
\text { Squares }\end{array}$ & df & $\begin{array}{l}\text { Mean } \\
\text { Square }\end{array}$ & $\mathbf{F}$ & Sig. \\
\hline \multirow{5}{*}{$\begin{array}{l}\text { Prokrastinasi } \\
\text { Akademik } \\
\text { (Y) * Locus } \\
\text { Of Control } \\
\text { (X1) }\end{array}$} & Between & (Combined) & 6202.097 & 42 & 147.669 & 1.084 & .362 \\
\hline & Groups & Linearity & 2582.100 & 1 & 2582.100 & 18.956 & .000 \\
\hline & & $\begin{array}{l}\text { Deviation } \\
\text { from } \\
\text { Linearity }\end{array}$ & 3619.996 & 41 & 88.293 & .648 & .942 \\
\hline & Within G & roups & 14847.377 & 109 & 136.214 & & \\
\hline & Total & & 21049.474 & 151 & & & \\
\hline \multirow{5}{*}{$\begin{array}{l}\text { Prokrastinasi } \\
\text { Akademik } \\
\text { (Y)* } \\
\text { Perfeksionis } \\
\text { me (X2) }\end{array}$} & Between & (Combined) & 5058.176 & 43 & 117.632 & .794 & .802 \\
\hline & Groups & Linearity & 380.916 & 1 & 380.916 & 2.573 & .112 \\
\hline & & $\begin{array}{l}\text { Deviation } \\
\text { from } \\
\text { Linearity }\end{array}$ & 4677.259 & 42 & 111.363 & .752 & .851 \\
\hline & Within G & roups & 15991.298 & 108 & 148.068 & & \\
\hline & Total & & 21049.474 & 151 & & & \\
\hline
\end{tabular}

Dilihat dari hasil perhitungan menunjukkan nilai sig. pada deviation from linierity untuk variabel Locus Of Control (X1) terhadap Prokrastinasi Akademik (Y) sebesar 0,942>0,05, sehingga dapat disimpulkan bahwa variabel locus of control dan prokrastinasi akademik mempunyai hubungan yang linier. Nilai sinifikansi pada deviation from linearity untuk variabel perfeksionisme (X2) terhadap prokrastinasi akademik (Y) sebesar 0,851>0,05 maka dapat disimpulkan bahwa variabel perfeksionisme dan prokrastinasi akademik mempunyai hubungan yang linier. 
3587 Hubungan antara Locus Of Control dan Perfeksionisme dengan Prokrastinasi Akademik pada Mahasiswa Akuntansi - Isni Mardiani, Sri Zulaihati, Ati Sumiati

DOI: https://doi.org/10.31004/edukatif.v3i6.805

Tabel 5. Hasil Perhitungan Uji Regresi Berganda

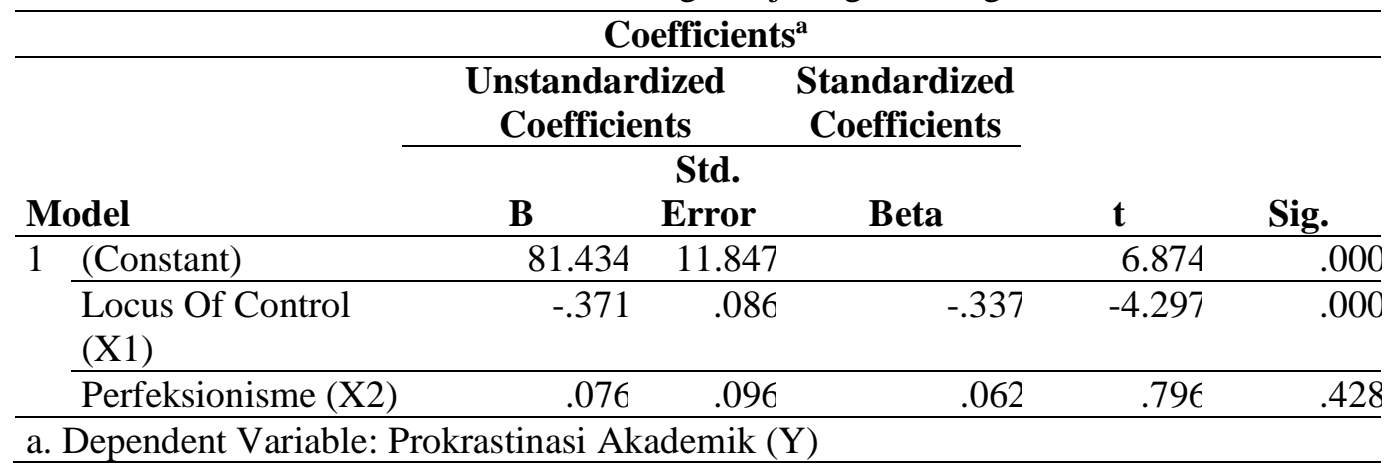

Berdasarkan tabel di atas diperoleh persamaan regresi $\hat{\mathrm{Y}}=81,434-0,371 \mathrm{X} 1+0,076 \mathrm{X} 2$. Nilai konstanta diperoleh sebesar 81,434 artinya jika locus of control dengan perfeksionisme bernilai 0, maka prokrastinasi akademik mempunyai nilai 81,434. Nilai koefisien regresi X1 sebesar - 0,371, artinya jika variabel locus of control (X1) meningkat sebesar 1 poin maka variabel prokrastinasi akademik (Y) akan menurun sebesar 0,371 pada nilai konstanta 81,434 dan diasumsikan koefisien perfeksionisme (X2) memiliki nilai tetap. Nilai koefisien Locus Of Control (X1) bernilai negatif, artinya bahwa pada saat Locus Of Control (X1) tinggi maka Prokrastinasi Akademik (Y) cenderug rendah, begitu pula sebaliknya apabila Locus Of Control (X1) rendah maka Prokrastinasi Akademik (Y) cenderung tinggi. Nilai koefisien regresi X2 sebesar 0,076 , berarti apabila variabel perfeksionisme (X2) meningkat 1 poin maka variabel prokrastinasi akademik (Y) akan meningkat sebanyak 0,076 pada nilai konstanta 81,434 dan diasumsikan koefisien locus of control (X1) memiliki nilai tetap. Koefisien X2 yang bernilai positif berarti terjadi hubungan yang positif antara perfeksionisme (X2) dengan Prokrastinasi Akademik (Y). Hal ini menunjukkan semakin tinggi perfeksionisme maka semakin tinggi prokrastinasi akademik, sebaliknya semakin rendah perfeksionisme maka semakin rendah prokrastinasi akademik. Menggunakan SPSS 26.0, berikut ini output uji F:

Tabel 6. Hasil Uji F

\begin{tabular}{|c|c|c|c|c|c|c|}
\hline \multicolumn{7}{|c|}{ ANOVA $^{a}$} \\
\hline \multicolumn{2}{|c|}{ Model } & Sum of Squares & df & $\begin{array}{c}\text { Mean } \\
\text { Square }\end{array}$ & $\mathbf{F}$ & Sig. \\
\hline \multirow[t]{3}{*}{1} & Regression & 2660.208 & 2 & 1330.104 & 10.777 & .000 \\
\hline & Residual & 18389.266 & 149 & 123.418 & & \\
\hline & Total & 21049.474 & 151 & & & \\
\hline & ependent $\mathrm{Va}$ & Prokrastinasi Aka & emik ( & & & \\
\hline & dictors: $(\mathrm{C}$ & at), Perfeksionisme & (2), Lc & Of Con & $X !)$ & \\
\hline
\end{tabular}

Dilihat dari tabel di atas diperoleh nilai signifikansi $0,000<0,05$. F hitung sebesar 10,777 dan nilai $\mathrm{F}$ tabel dapat dicari pada tabel statistic dengan taraf signifikansi $0,05 \mathrm{df} 1$ (jumlah variabel-1) atau $3-1=2$ dan df $2=\mathrm{n}-\mathrm{k}-1$ (n merupakan total responden dan k merupakan jumlah variabel bebas) atau $152-2-1=149$ sehingga nilai F table sebesar 3,06. F hitung 10,777 > F table 3,06 maka dapat disimpulkan variabel Locus Of Control (X1) dan Perfeksionisme (X2) berhubungan secara simultan dengan variabel Prokrastinasi Akademik (Y). Menggunakan SPSS 26.0, berikut merupakan output hasil uji t:

Tabel 7. Hasil Uji T

\begin{tabular}{|c|c|c|c|c|}
\hline \multicolumn{5}{|c|}{ Coefficients $^{a}$} \\
\hline & $\begin{array}{r}\text { Unst } \\
\mathrm{Cc}\end{array}$ & $\begin{array}{l}\text { ardized } \\
\text { ients }\end{array}$ & $\begin{array}{c}\text { Standardized } \\
\text { Coefficients }\end{array}$ & \\
\hline Model & B & $\begin{array}{l}\text { Std. } \\
\text { Error }\end{array}$ & Beta & Sig. \\
\hline
\end{tabular}


3588 Hubungan antara Locus Of Control dan Perfeksionisme dengan Prokrastinasi Akademik pada Mahasiswa Akuntansi - Isni Mardiani, Sri Zulaihati, Ati Sumiati

DOI: https://doi.org/10.31004/edukatif.v3i6.805

\begin{tabular}{llrrrrr}
\hline 1 & 81.434 & 11.847 & & 6.874 & .000 \\
\cline { 2 - 7 } & Locus Of Control (X1) & -.371 & .086 & -.337 & -4.297 & .000 \\
\cline { 2 - 7 } & Perfeksionisme (X2) & .076 & .096 & .062 & .796 & .428 \\
\hline
\end{tabular}

a. Dependent Variable: Prokrastinasi Akademik (Y)

Dilihat dari hasil uji t diperoleh t hitung untuk variabel Locus Of Control (X1) sebesar $(-4,297)$ dan t table $=(\alpha / 2 ; n-k-1)$ atau $(0,025-149)$ didapatkan nilai $t$ tabel sebesar 1,98. Maka dapat diketahui bahwa nilai t-hitung sebesar $(-4,297)<$ nilai t-tabel sebesar $(-1,98)$. Jadi dapat disimpulkan bahwa terdapat hubungan secara parsial antara variabel locus of control (X1) dengan variabel Prokrastinasi Akademik (Y). T hitung untuk variabel Perfeksionisme (X2) diketahui sebesar 0,796 < t-tabel 1,98. Jadi dapat disimpulkan bahwa tidak terdapat hubungan secara parsial antara variabel perfeksionisme (X2) dengan variabel Prokrastinasi Akademik (Y). Menggunakan SPSS 26.0, berikut output perhitungan koefisien determinasi:

Tabel 8. Hasil Perhitungan Uji Koefisien Determinasi

\begin{tabular}{lcccc}
\hline \multicolumn{4}{c}{ Model Summary } \\
\hline Model & R & R Square & $\begin{array}{c}\text { Adjusted R } \\
\text { Square }\end{array}$ & $\begin{array}{c}\text { Std. Error of } \\
\text { the Estimate }\end{array}$ \\
\hline 1 & $.355^{`}$ & .126 & .115 & 11.109 \\
\hline a. Predictors: (Constant), Perfeksionisme (X2), Locus Of Control \\
(X1)
\end{tabular}

Dilihat dari tabel di atas, nilai R Square sebesar 0,126. Maka dapat disimpulkan besarnya persentase hubungan variabel Locus Of Control (X1) dan Perfeksionisme (X2) untuk menjelaskan variabel Prokrastinasi Akademik (Y) secara simultan atau bersama-sama adalah 12,6\%.

Kebaruan dari penelitian yang peneliti lakukan bertujuan mengetahui antara variabel locus of control dan perfeksionisme dengan prokrastinasi akademik secara bersamaan (simultan) apakah terdapat hubungan yang signifikan dengan menggunakan uji F. Selain itu untuk menunjukkan hubungan positif atau negatif masing-masing variabel bebas serta untuk mengetahui arah hubung antara locus of control dan perfeksionisme dengan prokrastinasi akademik digunakan persamaan regresi berganda. Dengan ini ada hubungan antara locus of control dan perfeksionisme dengan prokrastinasi akademik secara simultan atau bersamaan dan signifikan. Selanjutnya, semakin tingkat locus of control rendah dan semakin tingkat perfeksionisme tinggi maka semakin tingkat prokrastinasi akademik tinggi. sedangkan semakin tingkat locus of control tinggi dan semakin rendah tingkat perfeksionisme maka semakin tingkat prokrastinasi akademik rendah.

Hubungan locus of control dengan prokrastinasi akademik menunjukkan hasil koefisien regresi yang negatif dan signifikan. Hasil penelitian ini sejalan dengan hasil penelitian terkait yaitu penelitian yang dilakukan (Soleh, Burhani, \& Atmasari, 2020) dalam penelitiannya menunjukkan bahwa dengan meningkatnya locus of control maka tingkat prokrastinasi akademik akan rendah. Hubungan antara kedua variabel bersifat negatif karena $\mathrm{R}$ hitung atau Pearson Correlations dalam analisis bernilai negatif atau dengan kata lain semakin meningkat locus of control maka tingkat Prokrastinasi Akademik akan semakin rendah atau negatif. Selanjutnya penelitian yang dilakukan oleh (S. A. Purnomo \& Izzati, 2013) hasilnya menunjukan bahwa semakin mahasiswa mempunyai nilai locus of control internal yang tinggi, maka tingkat prokrastinasi akademik semakin rendah. Namun Jika mahasiswa mempunyai internal locus of control rendah maka tingkat prokrastinasi akademik tinggi. Selain itu, menurut hasil penelitian (Sari \& Fakhruddiana, 2019) menunjukan bahwa antara locus of control dengan prokrastinasi mengerjakan tugas memiliki hubungan negatif signifikan. (Prihadi et al., 2018) prediksi pembelajaran ketidakberdayaan pada penundaan menjadi tidak signifikan

Ketika internal locus of control dikendalikan. Dengan kata lain, ketika siswa percaya bahwa mereka mengendalikan peristiwa mereka, semakin kecil kemungkinan mereka akan menunda-nunda melakukan tugastugas mereka karena perasaan tidak berdaya. Bertolak belakang dengan penelitian (Sarirah \& Apsari, 2019). 
3589 Hubungan antara Locus Of Control dan Perfeksionisme dengan Prokrastinasi Akademik pada Mahasiswa Akuntansi - Isni Mardiani, Sri Zulaihati, Ati Sumiati

DOI: https://doi.org/10.31004/edukatif.v3i6.805

bahwa pada penelitian ini menunjukan bahwa tidak berperan secara signifikan internal locus of control terhadap arousal procrastination. Didukung penelitian (Philips, 2012) yang menemukan antara internal locus of control tidak ada hubungan dengan prokrastinasi.

Hasil analisis regresi berganda menunjukan nilai positif namun tidak terdapat hubungan secara parsial antara perfeksionisme dengan prokrastinasi akademik. Hal ini berarti semakin tinggi ataupun semakin rendah tingkat perfeksionisme maka tidak ada hubungan pada tinggi ataupun rendahnya tingkat prokrastinasi akademik, apabila variabel perfeksionisme berdiri sendiri tanpa variabel lain yang menyertai. Hal ini Sejalan dengan penelitian yang dilakukan oleh (Srantih, 2014) bahwa tidak terdapat pengaruh yang signifikan pada mahasiswa yang sedang mengerjakan skripsi antara perfeksionisme dengan prokrastinasi akademik. Bertolak belakang dengan Penelitian yang dilakukan oleh (Smith, Sherry, Saklofske, \& Mushqaush, 2017) menyimpulkan perfeksionis memiliki hubungan negatif moderat dengan penundaan, sedangkan perhatian perfeksionis memiliki hubungan positif yang besar dengan penundaan.

Adapun hubungan secara bersama-sama variabel locus of control dan perfeksionisme dengan prokrastinasi akademik. Hal ini senada dengan penelitian Lasari et al. (2019) mengungkapkan locus of control dan perfeksionis secara bersama-sama berkontribusi secara signifikan terhadap prokrastinasi akademik. External locus of control dan perfeksionis semakin tinggi, maka prokrastinasi akademik siswa semakin tinggi, semetara semakin internal locus of control dan perfeksionis semakin rendah maka semakin rendah pula prokrastinasi akademik siswa. Dalam kenyataan sebenarnya yang memiliki hubungan dengan prokrastinasi akademik tidak hanya locus of control dan prokrastinasi akademik, masih banyak faktor lain yang dapat diteliti. Faktor lain yang dapat diteliti misalnya efikasi diri, konformitas, control diri, dan lain sebagainya. Bertolak belakang dengan penelitian (Boysan \& Kiral, 2016) antara penundaan akademik dan locus of control tidak dapat menemukan hubungan signifikan. Selanjutnya menemukan hubungan parsial dari prokrastinasi akademik dengan kritik orang tua dan kekhawatiran atas kesalahan.

Penelitian ini menujukan bahwa koefisien determinasi 0,126. Besarnya hubungan sebesar $12,6 \%$ dari variabel bebas locus of control dan perfeksionisme dengan prokrastinasi akademik, sedangkan sisanya sebesar 87,4\% dipengaruhi faktor lain. Makna sumbangan dalam penelitian ini berarti hubungan locus of control dan perfeksionisme dengan prokrastinasi akademik sebesar 15,60\% sisanya sebesar 84,40\% dipengaruhi oleh faktor lain. Menurut (Basri, 2018) faktor utama yang menyebabkan terjadinya perilaku prokrastinasi akademik antara lain faktor yang bersumber dari diri sendiri, meliputi beberapa kondisi psikologis, seperti kemampuan untuk mengatur waktu, motivasi, dan keyakinan. Sedangkan faktor eksternal yang berasal dari luar diri diantaranya faktor fasilitas sarana dan prasarana, faktor lingkungan sosial, hal ini terkait dengan dukungan dari orang-orang terdekatnya apakah memberikan perhatian yang cukup, serta kontrol perilaku yang sesuai. Pendapat lain dikemukakan oleh (S. A. Purnomo \& Izzati, 2013) menyatakan bahwa faktor lain yang dapat diteliti dalam penelitian lebih lanjut terkait dengan prokrastinasi akademik antara lain faktor kontrol diri, faktor dukungan sosial, faktor kepribadian, faktor sikap dan keyakinan serta faktor motivasi berprestasi. Faktor-faktor yang mempengaruhi prokrastinasi akademik dibagi menjadi dua kategori. Pertama-tama, faktor internal adalah faktor yang ada dalam diri individu. Faktor tersebut meliputi kondisi kesehatan individu dan kondisi fisik individu. Kondisi psikologis individu, misalnya self regulation, trait kepribadian, rendahnya self control dan tingkat kecemasan. Kedua, faktor eksternal adalah faktor yang ada di luar individu, antara lain kondisi lingkungan dan gaya pengasuhan orang tua (Ghufron \& Suminta, 2017).

Berdasarkan fakta hasil penelitian, diketahui bahwa tingkat prokrastinasi akademik tertinggi terdapat pada indikator penundaan untuk memulai dan menyelesaikan tugas. Hal ini terjadi bahwa prokrastinasi akademik dikarenakan kebiasaan mahasiswa melakukan perilaku menunda dalam memulai maupun menyelesaikan tugas sehingga tugas tidak dikerjakan tepat waktu. Indikator dengan persentase terendah yaitu melakukan aktivitas yang lebih menyenangkan, hal tersebut menunjukkan bahwa ketika melakukan prokrastinasi akademik, tidak selalu cenderung untuk melakukan kegiatan yang lebih menyenangkan. Melalui 
penjelasan tersebut maka sesuai dengan karakteristik mahasiswa Pendidikan Akuntansi dan Akuntansi Fakultas Ekonomi UNJ yang mayoritas menunda ketika memulai dan menyelesaikan tugas khusunya di bidang akademik sehingga terjadi perilaku prokrastinasi akademik tetapi jarang disebabkan oleh melakukan kegiatan lain yang lebih menyenangkan.

Pada hasil penelitian ini menunjukan fakta bahwa tingkat locus of control tertinggi terdapat pada indikator usaha. Hal ini menunjukkan bahwa locus of control dapat ditunjukkan dengan tingkat usaha yang tinggi dalam menyelesaikan tugas jika ingin memperoleh hasil yang baik. Keyakinan dalam mengendalikan diri akan ditunjukkan dengan adanya usaha yang tinggi jika ingin berhasil. Indikator terendah yaitu pengaruh dari orang ain, hal ini menunjukkan bahwa keyakinan dalam pengendalian diri tidak selalu diiringi dengan pengaruh dari orang lain. Fakta pada penelitian ini sesuai dengan karakteristik mahasiswa Pendidikan Akuntansi dan Akuntansi Fakultas Ekonomi UNJ, yakni banyak yang memiliki keyakinan dalam mengendalikan dirinya dalam mengerjakan tugas akademik selama masa kuliah dan terbiasa tidak banyak melakukan penundaan akademik. Mahasiswa Pendidikan Akuntansi dan Akuntansi dalam hal menyelesaikan skripsi juga cenderung melakukan usaha supaya bisa lulus tepat waktu namun juga sebagian dipengaruhi orang lain oleh sebab itu masih terjadi perilaku menunda.

Selanjutnya, berdasarkan fakta hasil penelitian menunjukkan bahwa tingkat perfeksionisme tertinggi terdapat pada indikator mengorganisir dalam melakukan sesuatu. Hal tersebut menunjukan bahwa seseorang yang perfeksionisme menganggap penting untuk mengorganisir sesuatu dan mencoba segala sesuatunya teratur untuk mendapatkan hasil sempurna. Indikator terendah yaitu tekanan dari orang tua, hal ini dikarenakan keinginan orang tua dalam menekan anaknya untuk bisa mewujudkan hal yang sesuai keinginan orang tua cenderung jarang terjadi sehingga seorang anak diberikan kebebasan untuk mewujudkannya. Penjelasan ini menggambarkan bahwa karakteristik mahasiswa Pendidikan Akuntansi dan Akuntansi mengorganisir dalam melakukan sesuatu untuk mencapai hasil sempurna dengan tidak begitu banyak tekanan dari orang tua.

\section{KESIMPULAN}

Hasil analisis data dan pembahasan yang diuraikan di atas dapat disimpulkan bahwa terdapat hubungan negatif antara locus of control dengan prokrastinasi akademik di lingkungan Pendidikan Akuntansi dan Akuntansi Fakultas Ekonomi UNJ. Hal ini berarti semakin tinggi mahasiswa memiliki locus of control sehingga prokrastinasi akademik semakin rendah. Sebaliknya, jika semakin rendah mahasiswa memiliki locus of control maka akan tingkat prokrastinasi akademik semakin tinggi. Selanjutnya, tidak terdapat hubungan positif antara perfeksionisme dngan prokrastinasi akademik di lingkungan Pendidikan Akuntansi dan Akuntansi Fakultas Ekonomi UNJ. Hal ini berarti semakin tinggi ataupun semakin rendah tingkat perfeksionisme maka tidak ada hubungan pada tinggi ataupun rendahnya tingkat prokrastinasi akademik, apabila variabel perfeksionisme berdiri sendiri tanpa variabel lain yang menyertai. Terdapat hubungan secara simultan antara Locus Of Control dan Perfeksionisme dengan Prokrastinasi Akademik dan sisanya variabel lain yang tidak diteliti.

\section{UCAPAN TERIMA KASIH}

Terimakasih kepada Rektor Universitas Negeri Jakarta Prof. Dr. Komarudin, M.Si. Dekan Fakultas Ekonomi Dr. Ari Saptono, S.E., M.Pd. Koordinator Program Studi Pendidikan Ekonomi Prof. Dr. Sri Indah Nikensari, M.Si. Ibu Dra. Sri Zulaihati, M.Si, selaku Dosen Pembimbing I dan Ibu Ati Sumiati, MM., selaku Dosen pembimbing II. Seluruh dosen penguji dan jajaran Dosen Fakultas Ekonomi Universitas Negeri Jakarta yang telah memberikan bimbingan dan ilmu selama proses penelitian. 
3591 Hubungan antara Locus Of Control dan Perfeksionisme dengan Prokrastinasi Akademik pada Mahasiswa Akuntansi - Isni Mardiani, Sri Zulaihati, Ati Sumiati

DOI: https://doi.org/10.31004/edukatif.v3i6.805

\section{DAFTAR PUSTAKA}

Arshuha, F., \& Amalia, I. (2019). Pengaruh Perbandingan Sosial Dan Perfeksionisme Terhadap Body Dissatisfaction Mahasiswi Pengguna Instagram. Jurnal Ilmiah Penelitian Psikologi: Kajian Empiris \& Non-Empiris, 5(2), 75-92.

Basri, A. S. H. (2018). Prokrastinasi Akademik Mahasiswa Ditinjau Dari Religiusitas. Hisbah: Jurnal Bimbingan Konseling Dan Dakwah Islam, 14(2), 54-77. Https://Doi.Org/10.14421/Hisbah.2017.142-05

Batubara, J., \& Asriatuzzekya. (2017). Contribution Locus Of Control And Self Esteem To Student Academic Procrastination. Jurnal Ilmu Pendidikan, Psikologi, Bimbingan Dan Konseling, 7(1), 54-62. Retrieved From Http://Ojs.Fkip.Ummetro.Ac.Id/Index.Php/Bk/Article/View/797

Boysan, M., \& Kiral, E. (2016). Associations Between Procrastination, Personality, Perfectionism, SelfEsteem And Locus Of Control. British Journal Of Guidance And Counselling, 45(3), 1-13. Https://Doi.Org/10.1080/03069885.2016.1213374

Fadila. (2016). Mengembangkan Motivasi Belajar Melalui Locus Of Control Dan Self Esteem. Jurnal Pendidikan Agama Islam, STAIN Curup, 1(01), 83-100.

Ghufron, M. N., \& Suminta, R. R. (2017). Teori-Teori Psikologi. Jogjakarta: Ar-Ruzz Media.

Ismail, F. (2018). Statistika Untuk Penelitian Pendidikan Dan Ilmu-Ilmu Sosial. Jakarta: Prenadamedia Group.

Jadidi, F., Mohammadkhani, S., \& Tajrishi, K. Z. (2011). Perfectionism And Academic Procrastination. Procedia - Social And Behavioral Sciences, 30, 534-537. Https://Doi.Org/10.1016/J.Sbspro.2011.10.104

Kurtovic, A., Vrdoljak, G., \& Idzanovic, A. (2019). Predicting Procrastination: The Role Of Academic Achievement, Self-Efficacy And Perfectionism. International Journal Of Educational Psychology, 8(1), 1-26. Https://Doi.Org/10.17583/Ijep.2019.2993

Lasari, D. M., Marjohan, \& Karneli, Y. (2019). Kontribusi Locus Of Control Dan Perfeksionis Terhadap Prokrastinasi Akademik Siswa Serta Implikasinya Dalam Pelayanan Bimbingan Dan Konseling Di SMAN 10 Padang. Journal Of Chemical Information And Modeling, 2(1), 1-28.

M, P. (2012). Philips, M. (2012). Does Locus Of Control Task Interest Have An Effect On Procrastination? Journal Of Learning And Motivation: 50(1),1-19.. Journal Of Learning And Motivation, 50(1), 1-19.

Pearlman-Avnion, S., \& Harduf, R. (2019). Procrastination, Perfectionism, And Locus-Of-Control In Academic Settings. Special School, LXXX(2), 108-124. Https://Doi.Org/10.5604/01.3001.0013.1973

Prihadi, K., Tan, C. Y. H., Tan, R. T. S., Yong, P. L., Yong, J. H. ., Tinagaran, S., ... Tee, Y. J. (2018). Mediation Role Of Locus Of Control On The Relationship Of Learned-Helplessness And Academic Procrastination Among College Students In Penang, Malaysia. International Journal Of Evaluation And Research In Education (IJERE), 7(2), 87. Https://Doi.Org/10.11591/Ijere.V7i2.12597

Priyatno, D. (2010). Teknik Mudah Dan Cepat Melakukan Analisis Data Penelitiaan Dengan SPSS. Yogyakarta: Gava Media.

Pujiyanti, A. (2017). Pengaruh Intesitas Mengikuti Mentoring ( LIQĀ', ) Dengan Prokrastinasi Akademik Mahasiswa. Ilmu Sosial Dan Pendidikan, 1, 13-20.

Purnomo, R. A. (2017). Analisis Statistik Ekonomi Dan Bisnis Dengan SPSS. Ponorogo: CV. Wade Group.

Purnomo, S. A., \& Izzati, U. A. (2013). Hubungan Antara Internal Locus Of Control Dengan Prokrastinasi Akademik Pada Mahasiswa Angkatan 2008 Yang Menghadapi Skripsi Di Fakultas Ilmu Pendidikan Universitas Negeri Surabaya. Character: Jurnal Penelitian Psikologi., 1(2), 1-10.

Rice, K. G., Richardson, C. M. E., \& Clark, D. (2012). Perfectionism, Procrastination, And Psychological Distress. Journal Of Counseling Psychology, 59(2), 1-15. Https://Doi.Org/10.1037/A0026643

Sari, W. L., \& Fakhruddiana, F. (2019). Internal Locus Of Control , Social Support And Academic Procrastination Among Students In Completing The Thesis. International Journal Of Evaluation And 
3592 Hubungan antara Locus Of Control dan Perfeksionisme dengan Prokrastinasi Akademik pada Mahasiswa Akuntansi - Isni Mardiani, Sri Zulaihati, Ati Sumiati

DOI: https://doi.org/10.31004/edukatif.v3i6.805

Research In Education (IJERE) Vol., 8(2), 363-368. Https://Doi.Org/10.11591/Ijere.V8i2.17043

Sarirah, T., \& Apsari, P. (2019). The Role Of Locus Of Control Toward Arousal Procrastination Among Students. Journal Psikodimensia, 18(1), 1. Https://Doi.Org/10.24167/Psidim.V18i1.1676

Smith, M. M., Sherry, S. B., Saklofske, D. H., \& Mushqaush, A. R. (2017). Clarifying The PerfectionismProcrastination Relationship Using A 7-Day, 14-Occasion Daily. Personality And Individual Differences, $112,117-123$.

Soleh, M., Burhani, M. I., \& Atmasari, L. (2020). Hubungan Antara Locus Of Control Dengan Prokrastinasi Akademik Pada Mahasiswa Psikologi IAIN Kediri Moh. Jurnal Happiness, 4(2), 104-115. Https://Doi.Org/10.1007/978-3-030-24436-1_17

Srantih, T. (2014). Pengaruh Perfeksionisme Terhadap Prokrastinasi Akademik Pada Mahasiswa Yang Sedang Mengerjakan Skripsi Di Fakultas Psikologi Uin Sunan Gunung Djati Bandung. Psympathic: Jurnal Ilmiah Psikologi, 1(1), 58-68. Https://Doi.Org/10.15575/Psy.V1i1.467

Sutrisno, A., Rini, A. P., \& Pratitis, N. T. (2018). Prokrastinasi Anggota Polrestabes Surabaya Ditinjau Dari Jenis Kelamin Dan Locus Of Control. Fenomena: Jurnal Psikologi, 1(1), 1-12. Https://Doi.Org/10.30996/Fn.V27i1.1498

Winarsunu, T. (2017). Statistik Dalam Penelitian Psikologi Dan Pendidikan. Malang: Universitas Muhammadiyah Malang.

Xie, Y., Yang, J., \& Chen, F. (2018). Procrastination And Multidimensional Perfectionism: A Meta-Analysis Of Main, Mediating, And Moderating Effects. Social Behavior And Personality, 46(3), 395-408. Https://Doi.Org/10.2224/Sbp.6680 